\title{
Nilsson et al., Figure S2
}

A
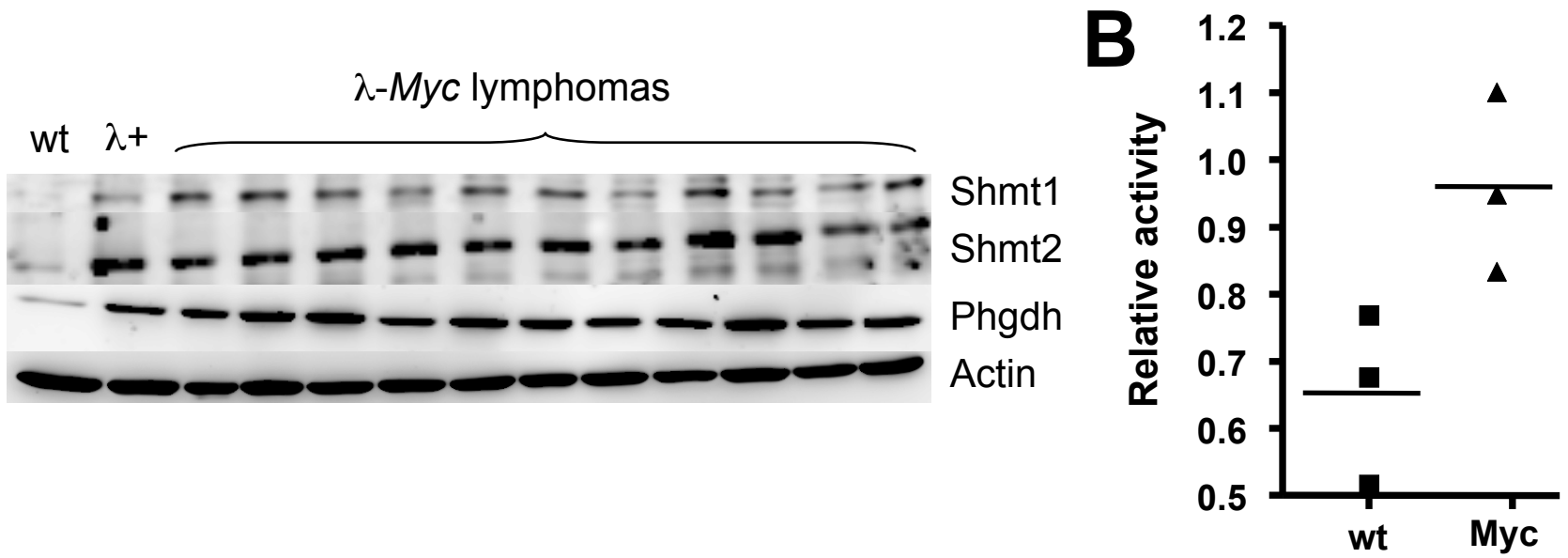

C

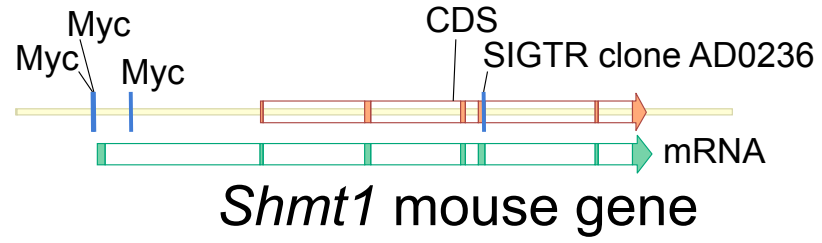

D $17847 \mathrm{bp}$

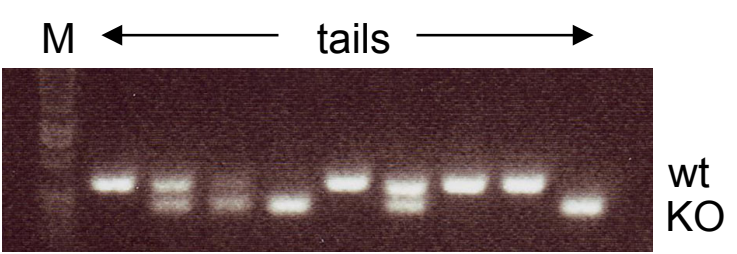

E

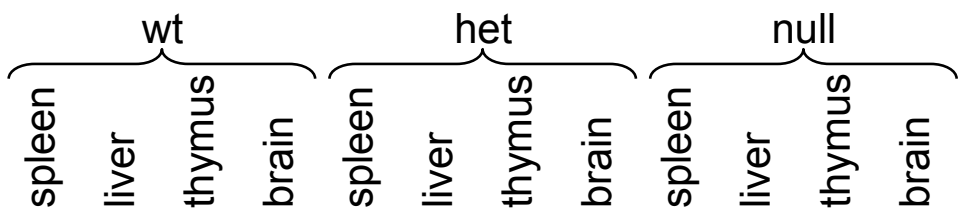

Shmt1

Shmt2

$\beta$-actin 